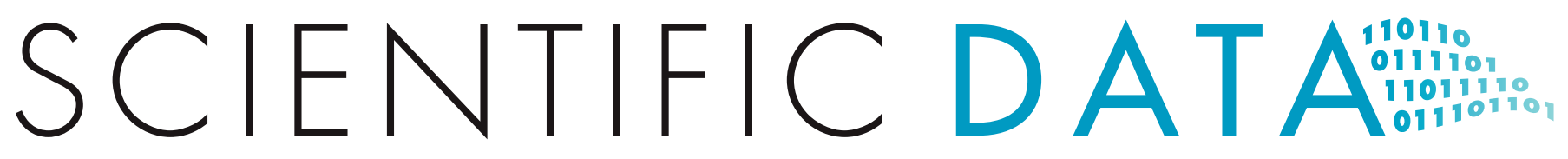

OPEN Corrigendum: Metagenome \title{
sequencing and 98 microbial genomes from Juan de Fuca Ridge flank subsurface fluids
}

\author{
Sean P. Jungbluth, Jan P. Amend \& Michael S. Rappé
}

Scientific Data 4:170037 doi:10.1038/sdata.2017.37 (2017); Published 28 March 2017; Updated 4 July 2017

Table 5 and Supplementary Table 1 contain an error in the Genbank accession provided for bin JdFR-98. The correct accession number is "MTPH00000000", not "MTPG00000000".

Open Access This article is licensed under a Creative Commons Attribution 4.0 International License, which permits use, sharing, adaptation, distribution and reproduction in any medium or format, as long as you give appropriate credit to the original author(s) and the source, provide a link to the Creative Commons license, and indicate if changes were made. The images or other third party material in this article are included in the article's Creative Commons license, unless indicated otherwise in a credit line to the material. If material is not included in the article's Creative Commons license and your intended use is not permitted by statutory regulation or exceeds the permitted use, you will need to obtain permission directly from the copyright holder. To view a copy of this license, visit http://creativecommons. org/licenses/by/4.0/
\end{abstract}

(c) The Author(s) 2017 